\title{
KEEP THE PACE: THE UNCORKED POTENTIAL OF WINE TOURISM IN ŠUMADIJA
}

\author{
Patrik Kubát ${ }^{1}$
}

Received: November 20, 2020 / Revised: March 8, 2021 / Accepted: April 9, 2021

(C) Association of Economists and Managers of the Balkans, 2021

\begin{abstract}
In the last two decades, Serbia has begun to re-establish itself within other wine-producing countries. One of the Serbian wine regions - Šumadija - caught hold of this opportunity and launched in the wine tourism industry. This paper, based on visits to Šumadija wineries and interviews with winemakers, is a survey of the present tourism infrastructures and wine histories. The aim is to explore the capacity of the wine industry in its attempt to develop tourism as a component of regional developmental progress. It is a review of the wine tourism situation and development in the Šumadija region, a survey of where it is today, and an assessment of its potential in the future. The author conducted interviews with winemakers and collected primary data from tourists at the regional wine event in 2017. In conclusion, recommendations are made for the further development of the area as a wine destination.
\end{abstract}

Keywords: Enotourism, Serbia, Tourism development, Wine region.

JEL classification $\mathrm{Z32} \cdot \mathbf{L} 83$

xkubat@mendelu.cz

1 Mendel University in Brno, Faculty of Business and Economics, Department of Marketing and Trade, Zemědělská 1665/1, 61300 Brno-sever, Czech Republic 


\section{INTRODUCTION}

In the territory of Serbia, wine has been made since the beginning of the Roman Empire. However, the country lacks the status of a tourist or vine-growing destination in the eye of the public. In the last two decades, Serbia has begun to re-establish itself within other wine-producing countries. Simultaneously, it has begun to announce its position on the world wine map and present its tourism potential (Hudelson, 2014a). This would then explain why Serbia was listed as one of Lonely Planet's 'Best Value' destinations of 2020 (Butler, 2019). In addition, wine embodies the perfect product for the further development of any region, where the conditions are convenient for its production. Presently, Serbia would like to represent itself to the world tourist market as a country of delicious food and high-quality beverages (Kubát, 2019a). In order to assume such a position, vine-growing areas need to cooperate on all of the various issues, overcome a number of barriers, and put together a vision that will lead to further expectant progress. For instance, one of the Serbian wine regions - Šumadija - caught hold of this opportunity, launching itself into the wine tourism industry at the regional level. Wine tourism, as a specific form of tourism in Serbia, is in its infancy (Sekulić et al., 2017). This explains the significance of research in the field of wine tourism, the need to explore the capacity of the wine industry in developing tourism as a component of regional developmental progress, as well as the importance of the present wine tourism foundation of one of the Serbian wine regions.

This paper, based on visits to Šumadija wineries and interviews with winemakers, is a survey of the present tourism infrastructures and (regional) wine histories. The aim is to explore the capacity of the wine industry to develop tourism as a component of regional developmental progress and state-of-the-art. It is a review of the wine tourism situation and development in the Sumadija region, a survey of where it is today, and an assessment of its potential for the future. This paper is more akin to an excursus, as it presents a wine-producing country that has begun to devote its interests to wine tourism activities. In conclusion, recommendations are made for the further development of the area as a wine destination.

\section{BACKGROUND}

\subsection{Wine industry development}

The cultivation of grapes in the territory of present-day Serbia dates back to the Roman Empire (Sekulić et al., 2016). Since the founding of the Serbian state, wine has been part of the local culture, and many Serbian rulers, especially the Nemanjic dynasty ( $11^{\text {th }}$ to $14^{\text {th }}$ century), have encouraged and promoted viticulture and winemaking throughout the area of Serbia and the Balkans, in general (Đenadić \& Rudež, 2018; Radovanović et al., 2017).

Over the centuries, there have been both expansions and slumps in the wine industry and its production. After World War II, Serbian viticulture decline, primarily due to the idea that wine should be accessible to all, meaning quantity took precedence over quality. Many vineyards were nationalized and controlled by the government (Enoteka Premier, 2002). The former Yugoslavia quickly became one of the world's ten largest wine producers. At the peak of its cultivation in the 1970s, the country produced over 6 million hectoliters per year.

The wine was mainly produced in large quantities, and in large agricultural associations with generally low-quality standards at all stages of the winemaking process. The 1980s brought a sharp decline in production and exports, which continued in the 1990s with the disintegration of 
Yugoslavia and the subsequent collapse of the Serbian economy. After the civil war, viticulture was finally able to recover slightly. In the first decade of the $21^{\text {st }}$ century, the Serbian wine industry began taking real steps toward progress (Radovanović et al., 2017). Many small and medium-sized private wineries, often family businesses, entered the market with a particularly high emphasis on the quality of the wine and the way it tasted. The recovery of the country's economy also contributed to the growth of domestic wine consumption (Lekić et al., 2018). In light of the increasingly favorable conditions for viticulture, Šumadija may be able to achieve a much more stable and high-quality level of wine production, which will only go to strengthen its market position (Kubát, 2019a).

According to data from the Statistical Office of the Republic of Serbia (SORS, 2017), the area of vineyards measures approximately 22.150 ha, with a production of 38.569 liters of wine. Mostly from this utilized vine-growing area is in a size of 2.01-5.00 ha. The Šumadija wine region has a production area of 8.424 ha. During the period in which the wine industry made its recovery in Serbia, the Ministry of Agriculture launched an initiative in 2008 to reform Serbian wine laws and reclassify wine regions (Ivanišević \& Jakšić, 2015; Tončev et al., 2016).

A new territorial wine division, replacing the classification from the 1970 s, divides the territory of Serbia into 3 units, consisting of 22 regions, 77 vine-growing districts, and many vine-growing oases (Ivanišević \& Jakšić, 2015). In Serbia, there are 369 registered, market-oriented wine producers, while there are about 80,000 producers engaged in the growing of grapes (Sekulić et al., 2016). The long tradition of Serbian viticulture has been renewed in the last ten years by several private producers, who have built contemporary cellars and have already established their renown outside of Serbia (Hudelson, 2014a).

Today, Serbian wines have grown in importance in the Balkans. With this in mind, Serbia has great potential for the development of various forms of tourism (Kubát, 2019a; Sekulić et al., 2016). As mentioned by Lonely Planet (2013), "Serbia is a land of rich hospitality, great food, and passionate revelry. Ditch the calorie counting and dig in!"

Traditional cuisine and local dishes are some of the attractions preferred by tourists also in other wine-producing countries surrounding Serbia (Wiluś, 2017). They are similar in geography, viticulture and historic background that unite them (Hudelson, 2014a). Bulgaria's wine production dating back to ancient times. Wine tourism is there still at the early stage of development due to underestimation of the significance of wine tourism in the whole territory. The profits from tourists are moderate as only a few tourists are interested and there absent places nearby vineyards where would be possible to taste wine (Stoykova, 2009). North Macedonia is aware of the overall existing potentials of their wine regions and related wine tourism (Marinoski et al., 2017).

Hudelson (2014b) believes that would be lucrative for Bosnia and Herzegovina to follow in the footsteps of its western neighbor - Croatia. The potential for wine tourism in Bosnia and Herzegovina benefits from the region's unique ability to produce distinctive wine varieties, its scenic beauty, and the advantage of low costs and wages.

Montenegro, as well as Romania and Albania, are other wine-producing countries that present an existing potential for wine tourism in the Balkan Peninsula (Hudelson, 2014a). These wine-producing countries are attempting to popularize their wine through tourism. (Wiluś, 2017). To achieve this goal, there is also endeavoring at the national level. In Romania, there is a government program called Romania - the country of wines (Ilieş et al., 2017). 


\subsection{Wine tourism definition basis}

Wine tourism is a concept that is still undergoing substantial development. There is a great deal to learn about how these two industries can make a positive contribution to one another and their shared regions throughout the world (Radovanović et al., 2017). The very nature of the wine industry allows the creation of a relationship with the tourism industry since wine is associated with relaxation, communication, nutrition, and hospitality, i.e. activities sought by tourists during their holidays (Zuegg, 2016). Therefore, wine and tourism are perceived as natural partners. From an economic point of view, however, both are exposed to tough competition. In the current saturated wine market, which is dominated by large producers, small wineries require local markets and so-called "cellar door sales", especially in emerging wine regions. This leads to the creation of brand awareness as well as an increase in sales (Tomljenović, 2006). At the same time, this can also act as a catalyst for the regional economic development of emerging tourism destinations that are blessed with the vine and as a tool for improving the image of the destination and diversification of products into new market segments for more established vine-growing regions (Getz, 2000; Tomljenović, 2006). Wine tourism is a substantial marketing tool for wine-related economic activities to increase revenues. The same goes for wine regions as they establish a brand name of origin and boost the rural economy (Hall et al., 2000). Wine constitutes an important element of the attractiveness of a destination region (Kubát, 2019b).

There are many definitions of wine tourism. Sekulić et al. (2016) declare that "wine tourism is widely recognized as a unique tourism product for visitors who are seeking an authentic multi-dimensional experience, and yet it simultaneously represents an innovative business opportunity for small-scale wine producers who wish to expand their wine production and meet the international demand". Pivac (2012) states that "wine tourism could be defined as visits to wineries and wine events with the same basic motive: wine tasting and enjoying the local food and specialties". Thus, as can be inferred from the given definitions, the basic products in wine tourism are wine and visits to wineries (Tončev et al., 2016).

However, there are also additional aspects that may enrich the primary product, including trips into nature, physical outdoor activities, food tasting, as well as supplementing the offer with complementary products (cultural goods) that are typically available near wineries (Byrd et al., 2016). Pivac (2012) mentions "a total wine experience", which is created by secondary products, activities, and motives for visiting the region with the primary products.

Tončev et al. (2016) conclude that such a "wine experience" includes: wine tasting and buying, socializing with friends, enjoying one's time outdoors, and appreciating the rural environment and vineyards. Wine tourism mainly involves tasting, however, the consumption or purchasing of wine, visits to wineries and vineyards, organizing and participating in wine tours, wine festivals and other wine-related events also contribute. The term "wine experience" refers to a class of themed tourism, in which contact with the wine is the focus, not the conclusion. For the development of wine tourism, winescape, i.e. vineyards, landscape, tasting rooms, and tourists' facilities, are exceedingly important (Hall et al., 2000).

\section{METHODOLOGY}

The foundation and structure of the methodology of this paper draw their inspiration from previous research pieces dedicated to wine tourism (Getz \& Brown, 2006; Getz, 2000; Hudelson, 2014a). The suggested criteria in wine destinations by Getz \& Brown (2006) and Getz (2000) for its development are contributing and helpful in ensuring a thriving wine tourism understructure in the region. 
Getz (2000) served as an inspiration of the point of view from three perspectives: wine producers (winemakers), consumers (tourists) and tourism agencies (representing the destinations). The author conducted a semi-structured interview with 9 out of 16 members of the Šumadija Winemakers Association, who were able to cooperate in this research, and were active in wine tourism activities at that time. This method provides the consistent exploration of key themes, while also allowing for the spontaneous probing of new issues as they arise in the conversation (Corbetta, 2003).

The interviews were held primarily in English with small insertions of Serbian terminology. Interpretation of qualitative data was performed using the transcription technique, specifically in the manner of a selective protocol (McLellan et al., 2003). In order to gain a comprehensive point of view on wine tourism in this region, primary data from tourists was collected by spreading a paper questionnaire at the traditional 54 $4^{\text {th }}$ Oplenac harvest wine event in October 2017 (Oplenacka Berba, 2019). A sample of 124 tourists randomly chosen was collected from which 98 were valid for this research. Table 1 profiles the respondents, showing basic demographics and socio-economic characteristics. The third perspective was given by visiting a destination and by cooperation with one of the local bodies - REDASP2 .

Table 1. Sample structure of tourists $(\mathrm{N}=98)$

\begin{tabular}{|l|l|c|}
\hline Category of respondents & Absolute number \\
\hline \multirow{4}{*}{ Gender } & men & 43 \\
\cline { 2 - 3 } & women & 55 \\
\hline \multirow{5}{*}{ Education } & less than 30 years & 17 \\
\cline { 2 - 3 } & $30-40$ years & 22 \\
\cline { 2 - 3 } & $41-50$ years & 28 \\
\cline { 2 - 3 } & $51-60$ years & 22 \\
\cline { 2 - 3 } & over 60 years & 9 \\
\hline \multirow{5}{*}{ Monthly income } & primary & 17 \\
\cline { 2 - 3 } & secondary & 33 \\
\cline { 2 - 3 } & university & 48 \\
\hline \multirow{5}{*}{ Place of residence } & less than 25000 dinars/210 $€$ & 24 \\
\cline { 2 - 3 } & $25000 / 210 €-35000$ dinars $/ 295 €$ & 23 \\
\cline { 2 - 3 } & $35001 / 295 €-45000$ dinars $/ 380 €$ & 21 \\
\cline { 2 - 3 } & more than 45000 dinars/380 $€$ & 30 \\
\hline & region of Šumadija & 69 \\
\cline { 2 - 3 } & Serbia out of Šumadija & 26 \\
\cline { 2 - 3 } & out of Serbia & 3 \\
\hline
\end{tabular}

Source: Own elaboration

\section{RESULTS AND DISCUSSION}

In building the Šumadija wine brand, none of the wineries are lacking in terms of associativity and involvement. Each of them cooperates with at least one other institution, usually the city. Four wineries cooperate with the tourist organization in the city. Every surveyed winery cooperates virtually with other wineries - this is thanks to their membership in the Šumadija Wine Associa-

$2 \quad$ Regional Economic Development Agency for Šumadija and Pomoravlje 
tion, where all participants (apart from one) see the advantage of being a member. Members of the Šmadija Wine Association strive to move the region to the forefront not only through their wine but now also through tourist services and the common regional brand (Vina Šumadije, 2017). Advantages can be seen in the joint organization of activities and marketing, the group's collective visibility and image, the certain level of prestige and, last but not least, the collegial help and recommendations for their activities connected to wine (Kubát, 2019b).

Nowadays, participation in both wine events and projects is an important part of the presentation and operation of a winery. Every winery participates and cooperates in these public activities. "Yes, this is our marketing," as was mentioned at The King Winery. However, these activities are not seen as being beneficial by three wineries, as was mentioned in one of these facilities: "One in ten events is profitable". The remaining winemakers see these activities as a form of marketing and promoting their business and their products. In most cases, these winemakers have several years of experience with wine production. Six wineries got into the production of wine thanks to their ancestors, and they represent the current successes of the family winemaking tradition. Others became interested in wine and its production relatively recently - between the years 20102013. Nevertheless, these wineries already operate at the level of other wine producers. The two most well-known regional wineries (The King Winery and Winery Aleksandrović) represent the family vine-growing tradition that has been going on for decades. According to production rates, three producers are ranked as medium-sized wineries, whereas the rest fall under the category of small (family) wineries. This corresponds to the fact that many small and medium-sized private wineries, often family businesses, entered the market within the first decade of the $21^{\text {st }}$ century, right as the wine industry made its recovery (Radovanović et al., 2017).

As already mentioned, Šumadija has a demand to become a well-known wine-growing region not only at the national level thanks to the quality of their wine but also for their services. They are developed in most wineries, one might say, at a slower pace. The winery services that are offered in the field of wine tourism include the following: wine tasting, selling wine directly from the winery, selling brandy and other assortments (honey, jam, etc.), visits to the cellar and vineyards, visits to the museum of wine and viticulture, and a day spent with a winemaker. When it comes to accommodation facilities, in all of the visited wineries they are absent.

Ambitions to increase the accommodation capacity provided by the winery are low. The winemakers prefer to build tasting rooms, or halls (Kubát, 2019b). Generally speaking, there is a lack of accommodation capacity in the wine region. In most cases, you can find accommodation in the city of Topola or one's private family dwellings. By way of offering these services, the wineries could show their interest in attracting tourists, something that corresponds to the answers given by all the wineries, when they said they would like to develop their winery to the satisfaction of the tourists with the help of new wine services. The tourists have been asked about wine services which they usually seek for. The majority seeks wine tasting and restaurants followed by accommodation, lectures about wine in the region (and its history) and visiting a wine cellar. Management of wineries, as well as a side of tourists, mainly endeavors wine tasting. The development of wine tourism contributes to the positioning and recognition of a certain tourist region and thus creates a competitive advantage. As a tourist destination, Šumadija has a lot to offer in this field tourists (Đenadić \& Rudež, 2018).

The surveyed wineries are also open to welcoming tourists at almost any time of the day. This alternative may be best described in the term "come-as-you-can" wine tourism (Kubát, 2019a). As noted by Byrd et al. (2016), the development of core, augmented, and ancillary services in a wine region are crucial for tourists as well as for wineries. For the development of wine tourism via a 
winery, it is essential to have feedback from tourists as well as other participants in this type of tourism. Some wineries have a problem attracting tourists or visitors in general.

Furthermore, many wineries do not keep a database or any other basic overview of their tourists. The location of the wineries in terms of the promotion of their whereabouts is not at a sufficient level. The favorable location of winery facilities remains key to the role of marketing (Hall et al., 2000; Kubát, 2019a). Choosing a favorable place in relation to at least some promotion is crucial in connecting supply (the winery) with demand (tourists). The main form of communication with tourists at all wineries was primarily the Internet (email, Facebook), followed by the use of a personal phone (SMS, mobile phone). This finding also corroborates tourists which mainly seek information about wine services and events on the Internet.

The second source of information for tourists is so-called word-of-mouth - a recommendation from friends, family, people in the region - followed by information from wine fairs, wine tasting and conferences, when they are already at these events. Other mentioned sources were newspapers, brochures, and tourist information centers. Word-of-mouth is a good promoter of a wine destination, which could create a positive image for the destination and recommend a destination to friends and relatives (Yen \& Wang, 2020). Pivac et al. (2020) confirm the use of Facebook as the main communication channel not just in Šumadija, but in the whole Serbia.

As Getz (2000) declares, it is important to consider in more detail other aspects of the location of/ for a winery, such as natural or infrastructural assets. Radovanović et al. (2017) recommend implementing tourist signage that shows the distance needed to travel from the nearest town to the winery. This signage is beneficial, both in the case of a planned visit or a random tourist passing by. Hudelson (2014a) contributes that most wineries throughout the Balkans are not surrounded by vineyards, rather they are located some distance from them. The same author also presented the first "in-the-vineyard" winery in Serbia, located in the Srem wine region. The research shows that the so-called "in-the-vineyard" wineries in the Šumadija wine region are well attended, as was stated by five surveyed wineries.

The above-mentioned factors are also linked to the location of the winery on the Internet. The wineries' presence online can help raise awareness of their business, and the likeliness that potential tourists will happen across them. The importance of this factor goes beyond the physical location of the winery itself, which also applies to the placement of online advertising and the use of online marketing. Four wineries do not have their websites, whereas three wineries do not carry out any activities on the Internet for potential tourists. These wineries are missing out on the opportunity of maintaining a lasting connection with tourists and showing them the possibilities of spending even more time at their business (cultural and sporting events, wine markets, open cellar events, etc.). Nowadays, these two aspects make for an indispensable connection between the winemaker and the tourist. Đenadić \& Rudež (2018) point out that the greatest number of wineries in Serbia is visited by up to 1.000 tourists a year. More than a half of them sell less than $20 \%$ of their wine production directly to their visitors - tourists. Very few wine tourism subjects offer restaurant service aside from wine tasting, as points this research too.

Structure of respondents in Table 1 present basic characteristic which may be crucial for wine event organizers, winery managers and Destination Management Organization (DMO) in a way of introducing these visitors' characteristic for better aiming of services and products and satisfying the visitors. It formulates and presents a typical wine event visitor, especially peculiar for an Oplenac harvest wine event. The predominant gender is a female person from the Šumadija region in age limit 41-50 years with a university degree with a monthly wage of more than 45000 dinars. 
As mentioned by Pivac (2012) the tourists come to a certain wine area to encounter and experience its character, food, way of life, cultural attractions and relaxation. Based on tourist travel lays the motive to get to know that which is different and yet inexperienced, hence diversity as an imperative in tourism. Consequently, Byrd et al. (2016) describe primary motives are mainly related to entertainment, education in the wine, winery and wine-producing area, wine tasting, food, and wine, socializing with other people, visiting art galleries, museums, historic sites, parks, monasteries, etc.

Regarding an improvement from the side of tourists, they would primarily suggest realizing more events concerning wine. Another improvement they suggest is more accommodation facilities, cooperation of wine and sport (more cycling routes and walking routes connecting wineries) and further cooperation with other wine countries/regions. Lastly, they have been asked to give a satisfactory mark for wine tourism experience in the Šumadija wine region (scale from 1-totally bad to 10 -perfect). An average point was 6.4. It has to be pointed that most of the respondents live in the Šmadija region so their perspective may be skewed or even captivated.

Wine tourism is generally enhanced by the proximity of non-wine tourist activities, locations, and attractions. A few examples include beaches, national parks, and historic sites (Hudelson, 2014a). In this respect, Šumadija can offer natural and historical sites, countless temples and monasteries, the presence of religious tourism, and other historical buildings. Šumadija region has significant natural and human resources for the development of rural tourism, which has not been adequately utilized (Mandarić et al., 2017).

Erdeji et al. (2013) show that the appeal for natural setting is the main reason to visit rural areas in Serbia generally. It should be noted that wine tourism does not have to be realized only (in connection) with wine, as it has much more to offer and the ability to support the whole tourist region of wine destinations (Zuegg, 2016). As was mentioned by one employee from REDASP: "In Šumadija, wine is inseparably associated with gastronomy." The term wine tourism refers to a group of thematic tourism, in which contact with the wine is the focus, not the target itself (Hall et al., 2000).

\section{FUTURE RESEARCH DIRECTIONS}

Good practices can be taken from different parts of the world (Hall et al., 2000). For instance, the Winemakers' Federation of Australia develops a national wine tourism strategy with funding from the Federal Government's Office of National Tourism. These objectives may also be useful and applicable within the Serbian wine tourism sphere. The main objectives of the strategy are raising the awareness and understanding of tourism in the wine industry, establishing wine tourism industry standards, increasing the skill level of wine tourism practitioners and employees, and, lastly, fostering links between the wine, food, and lifestyles of the local people.

An important primary impulse for tourists interested in visiting a wine region is the local attractions and sights. Šumadija should make better use of its attractive locations, a move which is sure to result in more tourists. Furthermore, the services provided to tourists should be improved in terms of quality, just as the locations and possible sources for more information about the actual wineries should be specified.

By envisaging new services, the wineries have the potential to stand out and move ahead of other wine regions. The creation and offer of new wine services and products have no boundaries. Furthermore, mentioned word-of-mouth in research is a crucial tool how to improve the image and 
increase the income of wine-producing areas, holding a wine cultural event is a good approach, which also is a growing trend (Yen \& Wang, 2020).

Further research should also focus on the dimensions of the winescape and characteristics of the tourists by means of specifying the wine tourist profile in this region. Thus, for the future success of wine tourism, the attitude of the wine industry and local population toward tourism, entrepreneurism, and economic cooperation is most important. A field of wine tourism in a practical way is spreading in a territory of Serbia between wine-producing areas and research is on the rise likewise.

This study is also aware of its limits, which have limited the research and range of presented results and should be eliminated in further studies. As limitations have been considered the time of the research itself and collecting data. Since this study was conducted four years ago. A situation with COVID-19 influenced a state of wine tourism development in a way of stagnation due to canceled wine events and other restrictions avoiding other activities connected to wine and tourism. Another limitation in the research and suggestion for future research is to increase the sample size of tourist respondents and collect primary data also from tourists in Serbian wine regions through a season and not just at a particular wine event.

\section{CONCLUSION}

Despite its advantages, the Šumadija wine region is still in the initial stage of wine tourism development. Regardless of its relatively prosperous natural, social, and cultural predispositions, Šmadija has yet to turn its comparative advantage into a competitive one. In the future, wine production may represent a significant part of the developmental potential of Serbia, which means more attention should be paid to the industry. However, the wine industry in Serbia currently poses at a higher level than that of wine tourism. This type of tourism is not yet well established and strengthened here. Subsidies for wineries, production, and the processing of wine have influenced the increase in the number of small wineries in the Šumadija wine region over the last fifteen years. Domestic winemakers are interested in engaging in this form of tourism, as Sekulić et al. $(2017,2016)$ ascertained as well. Therefore, it is reliable to say the spread and (quality) improvement of wine services will continue in this region.

As a wine region, Šumadija can achieve recognition and marketing visibility in both the national and European wine markets. The way to accomplish this is by formulating an integrated tourism product that will offer sophisticated tourists, apart from enjoying quality wine, the option to stay in an untouched, natural environment, socialize with friends, escape from their everyday stress and chaotic urban lifestyles, visit cultural, historical, and religious monuments, and enjoy rural tourism products together with the hospitality of the locals. In closing, one of the winery owners summarized the atmosphere and wine tourism situation in Šumadija with this poetic synopsis: "Wine, in the sense of a vineyard and a cellar, is neither a burden nor a trade for me. It is my privilege, my love, my satisfaction, and the lifestyle I live."

\section{ACKNOWLEDGMENT}

This research paper was written in collaboration with two projects [PEF_DP_2021015] and [FRRMS_IGA_2017/011] at the Internal Grant Agency of Mendel University in Brno and with the cooperation of REDASP in Šmadija, Serbia. 


\section{REFERENCES}

Butler, A. (2019, October 22). The best-value destinations for 2020. Lonely Planet. https://www. lonelyplanet.com/articles/affordable-destinations-best-in-travel

Byrd, E.T., Canziani, B., Hsieh, Y.C.J., Debbage, K., \& Sonmez, S. (2016). Wine tourism: Motivating visitors through core and supplementary services. Tourism Management, 52(C), 19-29. https:// doi.org/10.1016/j.tourman.2015.06.009

Corbetta, P. (2003). Social Research: Theory Methods and Techniques. SAGE Publications Ltd.

Đenadić, M., \& Rudež, J. (2018, June 2). Wine tourism as factor of tourism positioning in Serbia. Tourism International Scientific Conference Vrnjačka Banja - TISC, 3(2), 645-662. Retrieved from http://www.tisc.rs/proceedings/index.php/hitmc/article/view/80

Enoteka Premier. (2002). Serbian wines. http://www.enotekapremier.rs/en/

Erdeji, I., Gagić, S., Jovičić, A., \& Medić, S. (2013). Development of rural tourism in Serbia. J. Settel. Spat. Plann, 4(2), 309-315.

Getz, D. (2000). Explore wine tourism: management, development \& destinations. Cognizant Communication Corporation.

Getz, D., \& Brown, G. (2006). Critical success factors for wine tourism regions: a demand analysis. Tourism Management, 27(1), 146-158. https://doi.org/10.1016/j.tourman.2004.08.002

Hall, C.M., Sharples, L., Cambourne, B., \& Macionis, N. (Eds.). (2000). Wine Tourism Around the World: Development, Management and Markets. Butterworth- Heinemann.

Hudelson, J. (2014a). Eastern Promises: The Potential Future for Wine Tourism in the Balkans. American Journal of Tourism Management, 3(1B), 34-50. https://doi.org/10.5923/s.tourism.201402.05

Hudelson, J. (2014b). Sustainable Mountain Tourism: An Analysis of Bosnia-Herzegovina's Wine Tourism and its Future. SHS Web of Conferences, 12. http://dx.doi.org/10.1051/shsconf/20141201020

Ilieş A., Ilieş D.C., Tătar, C., \& Ilieş, M. (2017). Geography of Tourism in Romania. In Widawski K., Wyrzykowski J. (Eds.), The Geography of Tourism of Central and Eastern European Countries (pp. 329-374). Springer, Cham. https://doi.org/10.1007/978-3-319-42205-3_9

Ivanišević, D., Jakšić, D., \& Korać, N. (2015). Vinogradarski atlas Srbije. Republički zavod za statistiku Republike Srbije. http://publikacije.stat.gov.rs/G2015/Pdf/G201514009.pdf

Kubát, P. (2019a). Vývoj vinařského turismu a jeho úroveň v České republice, Chile a Srbsku. [Published master's thesis, Mendel University in Brno]. ProQuest Theses.cz.

Kubát, P. (2019b). Development of Wine Tourism in Šumadija Region. In D. Hampel (Ed.), PEFnet 2019 - 23rd European Scientific Conference of Doctoral Students (pp. 79-80). Mendel University in Brno.

Lekić, N., Savić, G., Knežević, S., \& Mitrovic, A. (2018). The efficiency analysis in small wineries in the Republic of Serbia. Economics of Agriculture, 65(4), 1529-1544. https://doi.org/10.5937/ ekoPolj1804529L

Lonely Planet. (2013). Eastern Europe. Lonely Planet.

Mandarić, M., Milićević, S., \& Sekulić, D. (2017). Traditional values in the function of promotion of Šumadija and Pomoravlje as rural tourism destinations. Ekonomika Poljoprivrede (1979), 64, 787-803. https://doi.org/10.5937/ekoPolj1702787M

Marinoski, N., Korunovski, S., \& Risteski, M. (2017). Possibilities for sustainable development of wine tourism in Demir Kapija and Florina. Yearbook-Faculty of Tourism and Business Logistics, 3(2), 58-67.

Mclellan, E., Macqueen, K.M., \& Neidig, J. L. (2003). Beyond the Qualitative Interview: Data Preparation and Transcription. Field Methods, 15(1), 63-84. https://doi.org/10.1177/1525822X02239573

Oplenacka Berba. (2019). Oplenac harvest-Municipality of Topola. https://oplenackaberba.com/

Pivac, T., Maksimović, M., \& Blesic, I. (2020). The Importance of Digital Marketing for Wineries and Development of Wine Tourism: Case Study of Serbia. 5th International Thematic Mono- 
graph: Modern Management Tools and Economy of Tourism Sector in Present Era, 241-251. https://doi.org/10.31410/tmt.2020.241

Pivac, T. (2012). Vinski turizam Vojvodine. Prirodno-matematički fakultet, Departman za geografiju, turizam i hotelijerstvo.

Radovanović, V., Đorđević, Ž.D., \& Petrović, J. (2017). Wine Marketing: Impact of Demographic Factors of Serbian Consumers on the Choice of Wine. Economic Themes 55(2), 199-215. https://doi.org/10.1515/ethemes-2017-0012

Sekulić, D., Petrović, A., \& Dimitrijević, V. (2017). Who are wine tourists? An empirical investigation of segments in Serbian wine tourism. Economics of Agriculture, 64(4), 1571-1582. https:// doi.org/10.5937/ekoPolj1704571S

Sekulić, D., Mandarić, M., \& Milovanović, V. (2016). Motivation of travelers for participation in wine tourism in Serbia. Economics of Agriculture, 63(4), 1237-1252. https://doi.org/10.5937/ ekoPolj1604237S

SORS - Statistical Office of the Republic of Serbia. (2017). Statistical Yearbook of the Republic of Serbia 2017. http://publikacije.stat.gov.rs/G2017/PdfE/G20172022.pdf

Stoykova, B. (2009). Successful practices in wine tourism following the example of Oryahovitsa Winery in Stara Zagora Region. Trakia Journal of Sciences, 7(3), 74-80.

Tomljenović, R. (2006). Wine tourism destination life-cycle. In Conference paper: Perspective of the rural tourism in the New Europe, GEOTOUR, Košice.

Tončev, M.J., Jovanović, D., Malićanin, M., \& Dimitrijević, B. (2016). Push and pull factors determining wine tourism development in the "Tri Morave" sub-region. Economics of Agriculture, 63(3), 781-800. https://doi.org/10.5937/ekoPolj1603781J

Vina Šumadije. (2017). Udruženje vinara Šumadije. http://vinasumadije.com

Wiluś, R. (2017). Geography of Tourism in Bulgaria. In Widawski K., Wyrzykowski J. (Eds.), The Geography of Tourism of Central and Eastern European Countries (pp. 71-107). Springer, Cham. https://doi.org/10.1007/978-3-319-42205-3_3

Yen, T.-F., \& Wang, M.-H. (2020). Wine Cultural Event as a Growing Phenomenon: Role of Novelty, Value and Satisfaction in Developing WOM. Asian Journal of Education and Social Studies, 10(2), 29-41. https://doi.org/10.9734/ajess/2020/v10i230264

Zuegg, I. (2016). Wine Tourism in South Tyrol. [Published bachelor thesis, Modul University]. 